\title{
Effect of Aspirin on the Developing Teeth of Neonates
}

\author{
Efecto de la Aspirina en el Desarrollo de los Dientes de Neonatos
}

\author{
"Shakila Nazir; **Sayed Naeem-ul-Hasan Naqvi; ${ }^{* * *}$ Masood Ahmed; ${ }^{* * * *}$ Abdul Hakeem Arain \& ${ }^{* * * * *}$ Naema Nazir
}

SHAKILA, N.; NAQVI, S. N. H.; AHMED, M.; ARAIN, A. H. \& NAEMA, N. Effect of aspirin on the developing teeth of neonates. Int. J. Morphol., 29(1):278-285, 2011.

SUMMARY: The objective of the present study was to evaluate the effect of aspirin (Acetyl Salicylic Acid) on the developing teeth of the fetus while the mothers were treated through out the pregnancy. Aspirin is a widely used analgesic and antipyretic drug used for symptomatic treatment. However, recent animal studies have indicated a potent teratogenicity of Acetyl Salicylic Acid. Its easy availability without prescription has been associated with high possibility of misuse, especially in the developing world. An experimental control study was carried out where female rabbits being treated with aspirin were taken as mammalian model, and their offspring were used to evaluate the developmental defects in teeth. Quantitative analysis of minerals in three types of the sample teeth, was done using scanning electron microscope and energy dispersive X-ray spectroscopy (SEM-EDX). Calcium was the most affected mineral and incisors and mandibular molars were found to be the most affected teeth. Voluminous variations were observed in the mineral contents of samples from the treated and control group, however, significant results could not be achieved. A larger sample size could possibly be needed to produce more conclusive results.

KEY WORDS: Aspirin; Teratogenic effect; Dentition; Female rabbits.

\section{INTRODUCTION}

Congenital abnormality may affect any part of the body resulting in malformation in the newborn. Like all other body tissues, dental tissues may also be affected by certain drugs during their developmental stages, if given during pregnancy. Oral and dental structures are frequently the sites of adverse drug reactions (Seymour \& Rudralingham, 2008). Almost every pregnant woman is exposed to some type of medication during pregnancy (Buhimschi et al., 2009). However, only a few drugs have specifically been tested for safety and efficacy during pregnancy. Various drugs can have adverse effects on teeth (Tredwin et al., 2005). Therefore, it is important to prescribe them having carefully considered their benefits vs. adverse effects that may occur as a result.

Dental tissues are sensitive to certain drugs, if they are used for a prolonged period or during pregnancy. Some reports have suggested that the misuse of aspirin by mothers late in pregnancy may cause reduced birth weight of the newborn or possible death of the fetus or newborn. These mothers had taken larger than the recommended doses of aspirin. While those taking the recommended doses of aspirin, did not show these effects. However, regular use of aspirin late in pregnancy may cause unwanted effects on the heart or blood flow in the fetus or the newborns. Also, use of aspirin during the last two weeks of pregnancy may cause bleeding problems in the fetus before or during delivery, or in the newborns (Xie et al., 1991). A single intrauterine exposure to a drug can affect the fetal structures undergoing rapid development at the time of exposure (Koren, 2007). Knowledge of adverse drug-induced oral effects helps health professionals to better diagnose oral disease, administer drugs and improve patient compliance (Femiano et al., 2008). Cappon and co-workers, in their study, did not find any teratogenic effect of Aspirin in rabbits even when large doses were administered on single day during specific windows of development (Cappon et al., 2003) however, teratogenicity

\footnotetext{
Professor, department of Oral Biology Baqai Dental College , Karachi, Pakistan.

** Professor, Department of Pharmacology, Baqai Institute of Pharmaceutical sciences, Karachi, Pakistan.

*** Professor Department of Anatomy, Baqai Medical college, Karachi, Pakistan.

${ }^{* * * *}$ Associate Professor, department of Community Dentistry Baqai Dental College, Karachi, Pakistan.

****** Post graduate trainee Abbasi Shaheed Hospital, Karachi, Pakistan.
} 
of aspirin has been reported at high doses in rodents (Berry $\&$ Nickols, 1979). There is scarcity of literature regarding the effect of aspirin on minerals in the dental tissues. Major accumulation of calcium and phosphorus takes place during the last trimester of pregnancy. SEM has been used by various researchers to analyze the structural alterations of the enamel surface (DeLaurier et al., 2006; Susheela et al., 1999). The SEM analysis has shown disturbed calcium levels, enamel aberrations and hypo mineralization of enamel in the primary teeth (Rythén et al., 2008). Chardi et al. (1998) used SEM to observe the effects of hypocalcaemia, induced by thyroparathyroidectomy, on the development of rat incisor enamel. They reported that the defects were limited to the outer enamel. Elevations in bone turnover support the likelihood that skeletal mineral is mobilized and restored during pregnancy and lactation. Indices of bone formation and resorption increase from early gestation (Prentice, 2003). Energy Dispersive X-ray microanalysis (EDX) has been used extensively by researchers to determine the Calcium $(\mathrm{Ca})$ and phosphorus $(\mathrm{P})$ contents of enamel and dentin. $\mathrm{Ca} \& \mathrm{P}$ ratio of sound enamel has a higher content of $\mathrm{Ca}$ than superficial and deep dentin (Salama, 2004). Developing enamel of rat incisors, dissected into a series of samples extending from the newly formed partially mineralized matrix to the mature enamel has shown an increasing hardness throughout the developing region but the $\mathrm{Ca} \& \mathrm{P}$ ratio remained fairly constant. Arnold \& Gaengler (2007) investigated the distribution of $\mathrm{Ca}, \mathrm{P}$, and $\mathrm{C}$ in predentin, mineralizing dentin, and mature dentin of human tooth buds by EDX element analysis (Hiller et al., 1975). The Ca and P content in enamel and circumpulpal dentin of permanent teeth was higher than in developing teeth. The $\mathrm{Ca} \& \mathrm{P}$ ratio was different between predentin and dentin areas reflecting different $\mathrm{Ca}$ and $\mathrm{P}$ compositions, but it was the same in mineralizing and young enamel. Assessing enamel hypoplasia separately, a prevalence of $15.1 \%$ was found, with the most affected teeth being the canines (33.6\%) and second molars (33.6\%) (Lunardelli \& Peres, 2005). A high prevalence of enamel defects in the first permanent molars amongst the children has been reported, particularly in European countries (Arrow, 2008).

\section{MATERIAL AND METHOD}

The present study included fourteen adult female rabbits weighing between 1.5 to $2.0 \mathrm{~kg}$ each. They were divided into two groups, each having seven female rabbits $(n=7)$. One group was treated with the aspirin while the second group was considered as control. The drug used was Disprin ${ }^{\circledR} 300$ mg. (Disprin ${ }^{\circledR}$ Reg. No. 000152). One tablet was dissolved in $25 \mathrm{ml}$ of the distilled water to prepare the drug for experimental purpose. One $\mathrm{ml}(8 \mathrm{mg} / \mathrm{kg})$ of the prepared drug was administered orally, twice a week to the female rabbits of the experimental group. Dose of the drug was determined according to the body weight of the animal, based on the Clark's rule (Koren), i.e.

$$
\text { Dose }=\frac{\text { Adult dose } \mathrm{x} \text { Weight }(\mathrm{Kg})}{70}
$$

All the treated animals were kept with equal number of their male partners at separate locations. Colored metallic wires and beads were used to identify the subjects and their number in the group. Yellow wire indicated the aspirin group and red wire, the control group. The drug was given according to the predetermined dose until the birth of offsprings. A record was maintained regarding the number of doses given to a particular animal in a predesigned proforma. Another proforma was designed to keep record of any toxicity that developed by the administered drug, such as diarrhea, ulceration, loss of physical activity, loss of interest in food, hair loss, edema, and weight variation in grams. The offspring of these treated female rabbits were used for the research purpose. After reaching the age of three months, these offsprings were sacrificed to obtain their upper and lower jaws. These jaws were cleaned and checked regarding the eruption, status and alignment of teeth. Rabbits are herbivores. Their teeth are unrooted and grow continually.

The dental formula of the rabbit teeth (Rouge, 2002) is: I-2/1: C-0/0: Pm-3/2:M-3/3 (Ï $2=28$ total teeth).

Rabbit's teeth are identified with their particular code numbers (20). They are as follows:

101- Right maxillary central incisor.

102- Right maxillary lateral incisor.

106- Right maxillary first premolar.

107- Right maxillary second premolar.

108- Right maxillary third premolar.

109- Right maxillary first molar.

110- Right maxillary second molar.

111- Right maxillary third molar.

201- Left maxillary central incisor.

202- Left maxillary lateral incisor.

206- Left maxillary first premolar.

207- Left maxillary second premolar.

208- Left maxillary third premolar.

209- Left maxillary first molar.

210- Left maxillary second molar.

211- Left maxillary third molar.

301- Left mandibular incisor.

307- Left mandibular first premolar.

308- Left mandibular second premolar. 
309- Left mandibular first molar.

310- Left mandibular second molar.

311- Left mandibular third molar.

401- Right mandibular incisor.

407- Right mandibular first premolar.

408- Right mandibular second premolar.

409- Right mandibular first molar.

410- Right mandibular second molar.

411- Right mandibular third molar.

For the extraction of teeth, various instruments were used such as, tweezers, artery forceps, alveolar bone cutter, inter dental scaler and contra angle hand piece with the round and fissure burrs (diamond point). The procedure was carried out by holding the crown of the tooth with the artery forceps and releasing it from its socket of alveolar bone by grinding the bundle bone of the alveolus with the help of diamond point fissure burr. The body of the mandible and maxilla was sectioned with the help of alveolar bone cutter, taking care not to damage the teeth. Extracted teeth were then washed by de-ionized or distilled water in a Dappen dish and preserved in $10 \%$ formalin in bottles, which were labelled with individual code numbers for each sample of the tooth. Analysis of three minerals i.e. calcium, phosphorous, and magnesium was done in the teeth of upper and lower arches of both the experimental and control groups.

All three types of teeth, i.e. central incisors, first premolars and first molars of each quadrant of the maxillary and mandibular arches were included in the study.

This inclusion criteria could possibly provide sufficient information to draw a conclusion.

Twelve teeth were taken from each animal of experimental and control group, therefore the total number of teeth (samples) included in the study was $(12 \times 7 \times 2) 168$.

Codes of the teeth included in the study:

$[(101,106,109)$,$] - Right maxillary arch.$

[(201, 206, 209,)] - Left maxillary arch.

$[(301,307,309)$,$] - Left mandibular arch.$

[(401, 407, 409,)] - Right mandibular arch.

Analysis of the sample by SEM-EDX. Quantitative analysis of mineral contents of the sample teeth was done by using scanning electron microscope and energy dispersive X-ray spectroscopy (SEM-EDX). Each sample was coated with gold up to $300^{\circ} \mathrm{A}$, using Quick Auto Coater, model no. JFC-1500 Jeol. SEM used was (6380A Jeol) with EDS detector (Ex-54175 Jmu Jeol).
Parameters were kept uniform for each sample i.e. accelerating voltage $15.0 \mathrm{kV}$, magnification 10,000, standard less quantification technique with ZAF correction (UCLEMA, 2009), SSM dead time (Egerton, 2005) about $20-45 \%$. Results of the quantitative analysis obtained were expressed in mass percentage which is described as (Cambuddy mass percentage, 2009):

Mass percentage $=$ mass of substance $/$ mass of solution) İ 100.

The mass percentages of $\mathrm{Ca}, \mathrm{P}$ and $\mathrm{Mg}$ in the samples of the teeth were analyzed.

Statistical analysis of the data was done using SPSS version 13. Continuous response data of the mineral contents i.e. $\mathrm{Ca}, \mathrm{P}$ and $\mathrm{Mg}$ of the selected dentition were included. Numerical figures from the data were expressed as Mean and Standard Deviation (SD). Statistical comparison of the continuous data profile of the experimental and control group, based on dichotomous, was done by using student's t-test. Statistical significance was recorded in terms of Pvalues, and a P-value $\leq 0.05$ was considered as statistically significant.

\section{RESULTS}

Results of the quantitative analysis obtained were expressed in mass percentage.

\section{Aspirin Treated Group}

\section{Calcium}

Maxillary Incisors have (Mean $\pm \mathrm{SD}$ ) $8.99 \pm 5.61$, the control is $9.81 \pm 2.33$, with the P-value $0.73 \geq 0.05$ (Table I, Fig. 1).

Maxillary Premolars have (Mean \pm SD) $8.85 \pm 2.40$, the control is $8.27 \pm 2.77$, with the P-value $0.68 \geq 0.05$ (Table I, Fig. 1).

Maxillary molars have (Mean \pm SD) $9.66 \pm 2.67$, the control is $8.89 \pm 2.67$, with the P-value $0.60 \geq 0.05$ (Table I, Fig. 1.)

Mandibular Incisors have (Mean \pm SD) $9.19 \pm 2.77$, the control is $10.15 \pm 3.83$, with the P-value $0.59 \geq 0.05$ (Table II, Fig. 2).

Mandibular Premolars have (Mean \pm SD) $9.07 \pm 2.71$, the control is $9.81 \pm 2.51$, with the P-value $0.60 \geq 0.05$ (Table II, Fig. 2).

Mandibular molars have (Mean \pm SD) $7.33 \pm 2.69$, the control is $10.39 \pm 3.11$, with the P-value $0.07 \geq 0.05$ (Table II, Fig. 2).

\section{Phosphorous}

Maxillary Incisors have (Mean $\pm \mathrm{SD}$ ) $6.33 \pm 2.91$, the control is $6.74 \pm 2.02$, with the P-value $0.76 \geq 0.05$ (Table I, Fig. 1).

Maxillary Premolars have (Mean \pm SD) $6.12 \pm 2.36$, the control is $5.30 \pm 1.37$, with the P-value $0.44 \geq 0.05$ (Table I, Fig. 1). 
Maxillary molars have (Mean \pm SD) $7.39 \pm 1.3$, the control is 6.77 \pm 2.38 , with the P-value $0.56 \geq 0.05$ (Table I, Fig. 1 ).

Mandibular Incisors have (Mean \pm SD) $6.64 \pm 1.94$, the control is $6.28 \pm 2.15$, with the P-value $0.74 \geq 0.05$ (Table II, Fig. 2). Mandibular Premolars have (Mean \pm SD) $6.36 \pm 0.98$, the control is $7.27 \pm 1.65$, with the P-value $0.23 \geq 0.05$ (Table II, Fig. 2). Mandibular molars have (Mean \pm SD) $5.15 \pm 2.00$, the control is $7.42 \pm 2.37$, with the P-value $0.07 \geq 0.05$ (Table II, Fig. 2).

\section{Magnesium}

Maxillary Incisors have (Mean $\pm \mathrm{SD}$ ) $0.64 \pm 0.16$, the control is $0.33 \pm 0.11$, with the P-value $0.00 \leq 0.05$ (Table I, Fig. 1).

Maxillary Premolars have (Mean \pm SD) $0.87 \pm 0.28$, the control is $0.63 \pm 0.15$, with the P-value $0.07 \geq 0.05$ (Table I, Fig. 1).

Maxillary molars have (Mean \pm SD) $0.97 \pm 0.26$, the control is $0.79 \pm 0.19$, with the P-value $0.16 \geq 0.05$ (Table I, Fig. 1).

Mandibular Incisors have (Mean \pm SD) $0.70 \pm 0.24$, the control is $0.60 \pm 0.38$, with the P-value $0.53 \geq 0.05$ (Table II, Fig. 2).

Mandibular Premolars have (Mean \pm SD) $0.81 \pm 0.22$, the control is $0.70 \pm 0.12$, with the P-value $0.28 \geq 0.05$ (Table II, Fig. 2).

Mandibular molars have (Mean $\pm \mathrm{SD}$ ) $0.73 \pm 0.24$, the control is $0.99 \pm 0.32$, with the P-value $0.11 \geq 0.05$ (Table II, Fig. 2).

Analysis of calcium and phosphorous showed insignificant differences in all the types of the teeth of aspirin treated group compared to the control group. As far as magnesium was concerned, it showed a significant difference in maxillary incisors with the P-value $0.001<0.05$.

\section{DISCUSSION}

A low incidence of malformations with acetyl salicylic acid in rabbits, for cardiovascular development and midline closure, has been reported (Cappon et al.). There is scarcity of literature regarding the effect of aspirin on minerals in the dental tissues. The study of Grace et al. revealed the local erosive effects of aspirin-chewing on the human enamel (Grace et al., 2004). However it cannot be compared with the present study where aspirin was administered systemically.

Cappon et al. colleagues did not find any external, visceral or skeletal malformations associated with Acetyl Salicylic Acid administration throughout organogenesis or with single dose administration during critical developmental windows (Cappon et al.).

A teratogenic effect of aspirin at high doses in rodents has been reported (Berry \& Nickols) whereas, in the present study, the doses of the drug were predetermined according to the body weight of the animal. Aspirin is an original NSAID. Aspirin and other NSAIDs may inhibit bone loss and preserve bone mineral density (BMD) in vitro and in animal models (Bauer et al., 1996). Most of the experimental work has been reported showing the effects of aspirin on the density of bone (Lane et al., 1997; Carbone et al., 2003), but there is no data available regarding the effect of the drug on the individual minerals. The present study revealed the effect of the aspirin on three minerals of tooth i.e. calcium, phosphorous and magnesium.

Teeth have three types of mineralized tissues i.e. enamel, dentine and cementum. Enamel makes up the protective outer surface of anatomic crown (mostly inorganic, calcified), having $95 \%$ calcium hydroxyapatite, $4 \%$ water, and $1 \%$ organic matter (Woelfel \& Scheid, 1997). Dental enamel is the hardest tissue in the vertebrate body, containing long, thin crystallites of substituted hydroxyapatite (Paine \& Snead, 2005).

It is quite noticeable that the inorganic component of all the mineralized body tissues (bone, enamel, dentine and the cementum) is the same, i.e. "Hydroxyapatite". It could then be hypothesized that any external stimuli, which can affect bone or bone precursor cells, might also influence the dental tissues, their precursor cells and the mineralizing tissues of the teeth during the stages of development.

\begin{tabular}{lcccc}
\hline \multirow{2}{*}{ Teeth } & \multirow{2}{*}{ Minerals } & \multicolumn{2}{c}{ Mean \pm SD } & \multirow{2}{*}{ P-value } \\
\cline { 3 - 4 } Incisors & $\mathrm{Ca}$ & $9.81 \pm 2.33$ & $8.99 \pm 5.61$ & 0.73 \\
\cline { 3 - 4 } & $\mathrm{P}$ & $6.74 \pm 2.02$ & $6.33 \pm 2.91$ & 0.76 \\
& $\mathrm{Mg}$ & $0.33 \pm 0.11$ & $0.64 \pm 0.16$ & 0.00 \\
Premolars & $\mathrm{Ca}$ & $8.27 \pm 2.77$ & $8.85 \pm 2.40$ & 0.68 \\
& $\mathrm{P}$ & $5.30 \pm 1.37$ & $6.12 \pm 2.36$ & 0.44 \\
& $\mathrm{Mg}$ & $0.63 \pm 0.15$ & $0.87 \pm 0.28$ & 0.07 \\
Molars & $\mathrm{Ca}$ & $8.89 \pm 2.67$ & $9.66 \pm 2.67$ & 0.60 \\
& $\mathrm{P}$ & $6.77 \pm 2.38$ & $7.39 \pm 1.39$ & 0.56 \\
& $\mathrm{Mg}$ & $0.79 \pm 0.19$ & $0.97 \pm 0.26$ & 0.16 \\
\hline
\end{tabular}

Table I. Showing Mass Percentage and the statistical significance of the minerals in the maxillary teeth of the experimental and control groups. 


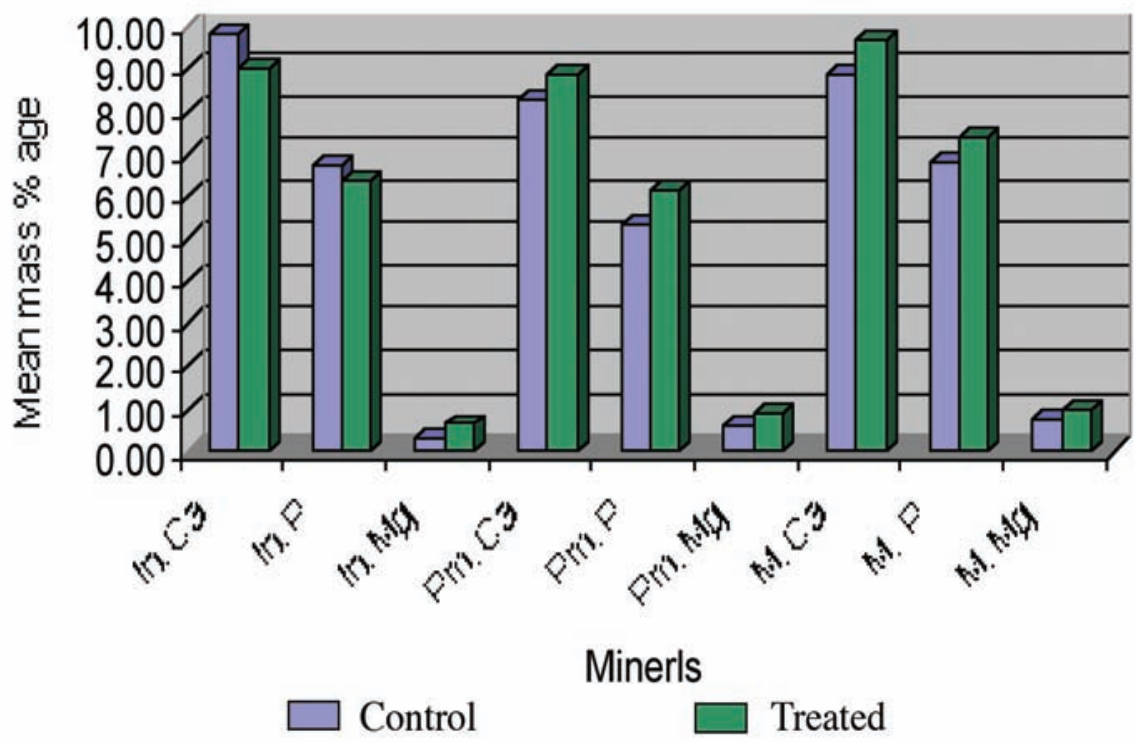

Fig. 1. Sowing Mean mass percentage of minerals in maxillary teeth.

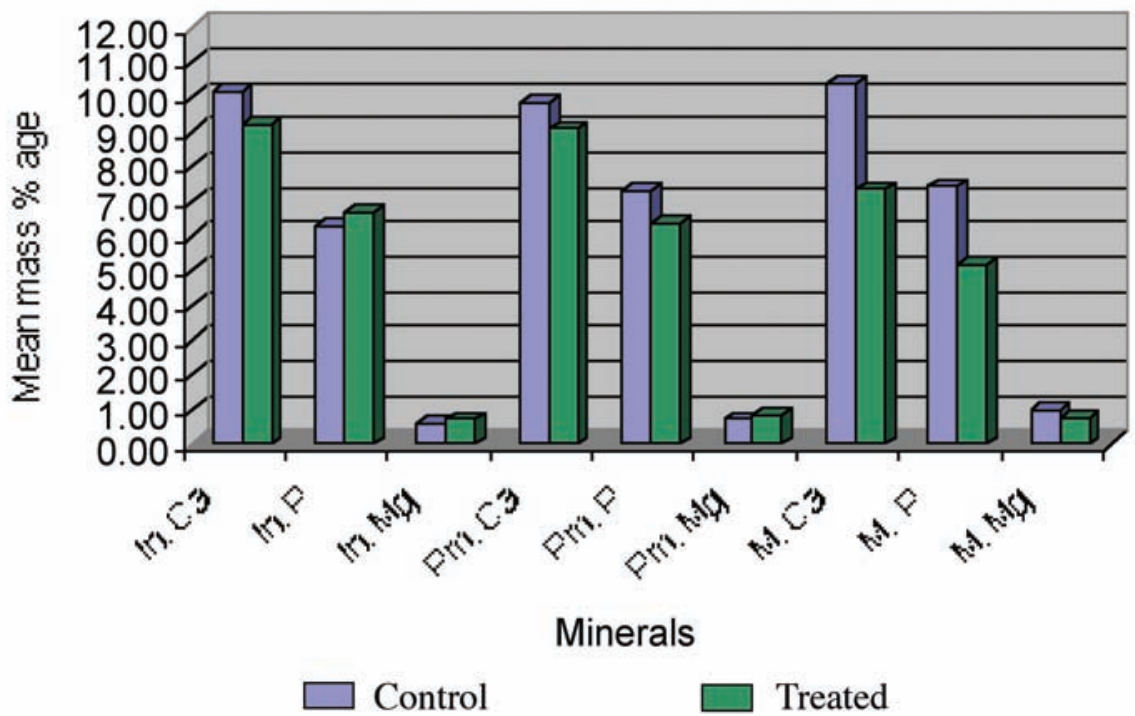

Fig. 2. Showing Mean mass percentage of minerals in mandibular teeth.

\begin{tabular}{lcccc}
\hline \multirow{2}{*}{ Teeth } & \multirow{2}{*}{ Minerals } & \multicolumn{2}{c}{ Mean \pm SD } & \multirow{2}{*}{ P-value } \\
\cline { 2 - 4 } & & Control & Treated & \\
\hline \multirow{3}{*}{ Incisors } & $\mathrm{Ca}$ & $10.15 \pm 3.83$ & $9.19 \pm 2.77$ & 0.59 \\
& $\mathrm{P}$ & $6.28 \pm 2.15$ & $6.64 \pm 1.94$ & 0.74 \\
& $\mathrm{Mg}$ & $0.60 \pm 0.38$ & $0.70 \pm 0.24$ & 0.53 \\
Premolars & $\mathrm{Ca}$ & $9.81 \pm 2.51$ & $9.07 \pm 2.71$ & 0.60 \\
& $\mathrm{P}$ & $7.27 \pm 1.65$ & $6.36 \pm 0.98$ & 0.23 \\
& $\mathrm{Mg}$ & $0.70 \pm 0.12$ & $0.81 \pm 0.22$ & 0.28 \\
Molars & $\mathrm{Ca}$ & $10.39 \pm 3.11$ & $7.33 \pm 2.69$ & 0.07 \\
& $\mathrm{P}$ & $7.42 \pm 2.37$ & $5.15 \pm 2.00$ & 0.07 \\
& $\mathrm{Mg}$ & $0.99 \pm 0.32$ & $0.73 \pm 0.24$ & 0.11 \\
\hline
\end{tabular}

Table II. Showing Mass Percentage and the statistical significance of the minerals in the mandibular teeth of the experimental and control groups. 
Results of the present study showed decreased calcium in maxillary and mandibular incisors and in mandibular premolars and molars in the experimental group as compared to the control group, whereas magnesium decreased in mandibular molars. According to the findings of this study, calcium was the most affected mineral and incisors and mandibular molars were the most effected teeth. A possible explanation put forward for this is that, the development, differentiation and formation of incisors start before premolars and molars (Ash, 1993), so their duration of exposure to the drug treatment was maximum during this study.

Ranggard \& Noren (1994) reported that the hypocalcemia can interfere with amelogenesis resulting in enamel abrasions and delayed mineralization. The transcriptional mechanisms underlying tooth development are only now being understood. Smith \& Nanci (1995) reported that tooth formation and mineralization is controlled by epithelial cells of enamel organ.

Zhang et al. (2005), reported a key role of Bmp4 in cyto differentiation and enamel and dentine formation by regulating ameloblast and odontoblast cyto differentiation (Andl et al., 2004). Zhang et al. has reported an inductive role of Bmps, TGF B and integrin a1 in the differentiation of mineralized tissue.

Aspirin and other NSAIDs inhibit the synthesis of prostaglandins through cyclooxygenase (COX) pathway. The two recognized forms of this enzyme, cyclooxgenase1 (cox-1) and cyclooxygenase-2 (Cox-2), are encoded by two separate genes (Xie et al.).

Zeng et al. (2003) reported the critical role of COX2 in mesenchymal cell differentiation during skeletal repair. Prostaglandin A derivative has been found to enhance the mineralization as effectively as Vit D3 and possibly by stimulating expression of various genes (Koshihara et al., 1991). Contrary to that Amendt et al. (1999), found that NSAID inhibit the cell proliferation and arrest the cell cycle. Addition of prostaglandin E1, E2 and F2a could not rescue the suppressor effect of NSAID. They concluded that this inhibitory effect of NSAID is probably via affecting expression of cell cycle regulators, but not prostaglandins. Ptx 2 is the earliest transcription factor that is selectively present in oral ectoderm. Mutation of this gene has been associated with missing teeth, microdontia, hypodentia and misshapen teeth.

Andl et al. have reported an essential role of beta catenin in early tooth development. According to them, this molecule is critical in early cyto differentiation and is expressed in odontoblast progenitor cells and odontoblast. Aspirin has been reported to reduce the formation of dentin through a mechanism that reduces the incorporation of collagen precursors into odontoblast.

The present study is an attempt to evaluate the in utero effects of aspirin on the chemical composition of the teeth. According to the earlier studies, the most affected teeth were the second molars $(44.4 \%)$, followed by the first molars (23.5\%) (Lunardelli \& Peres). Contrary to the earlier studies, the present study has shown a high prevalence of aspirin associated developmental defects in molars and incisors (Andl et al.).

A large variation within the samples from the control and the treatment group results (Table I and II) have been shown in the present study which has overshadowed any aggregate differences between the groups. A large sample size could possibly determine more conclusive results.

In conclusion, the use of aspirin for a prolonged period of time during pregnancy has shown an association with birth defects in the teeth of the neonates of rabbits. Most affected teeth found in this study were the incisors and mandibular molars and the most affected minerals were calcium and magnesium. Prevention of the developmental defects of teeth caused by the in utero exposure of the drug is possible. The drugs should only be used by doctor's prescription, especially during pregnancy, avoiding in every way the possibility of teratogenic effect on the dentition of the newborns.

SHAKILA, N.; NAQVI, S. N. H.; AHMED, M.; ARAIN, A. H. \& NAEMA, N. Efecto de la aspirina en el desarrollo de los dientes de neonatos. Int. J. Morphol., 29(1):278-285, 2011.

RESUMEN: El objetivo del estudio fue evaluar el efecto de la aspirina (ácido acetilsalicílico) sobre el desarrollo de los dientes en fetos de conejos, cuyas madres fueron tratadas durante toda la gestación. La aspirina es un fármaco ampliamente utilizado como analgésico y antipirético para el tratamiento sintomático. Sin embargo, estudios recientes en animales han indicado una teratogenicidad potente por parte del ácido acetilsalicílico. Su fácil disponibilidad, sin la necesidad de receta médica, se ha asociado con una alta posibilidad de su mal uso, especialmente en el mundo desarrollado. Se diseñó un estudio de control experimental, donde conejos hembras fueron tratadas con aspirina, tomándose como modelo de mamíferos, y sus crías fueron utilizadoa para evaluar los defectos en el desarrollo de los dientes. Se realizó el análisis cuantitativo de tres tipos de minerales en los dientes de la muestra mediante microscopio electrónico de barrido y espectroscopía de rayos X por dispersión de energía (SEM-EDX). El calcio fue el mineral más afectado y los incisivos y molares inferiores fueron como los dientes más afectados. Grandes varia- 
ciones se observaron en el contenido mineral de las muestras de los grupos tratado y control, sin embargo, no se lograron resultados significativos. Un tamaño de muestra más sería necesario para producir resultados más concluyentes.

PALABRAS CLAVE: Aspirina; Efectos teratogénicos; Dentición; Conejos hembra.

\section{REFERENCES}

Andl, T.; Ahn, K.; Kairo, A.; Chu, E. Y.; Wine-Lee, L.; Reddy, S. T.; Croft, N. J.; Cebra-Thomas, J. A.; Metzger, D.; Chambon, P.; Lyons, K. M.; Mishina, Y.; Seykora, J. T.; Crenshaw, E. B. 3rd. \& Millar, S. E. Epithelial Bmpr1a regulates differentiation and proliferation in postnatal hair follicles and is essential for tooth development. Development, 131(10):2257-68, 2004.

Amendt, B. A.; Sutherland, L. B. \& Russo, A. F. Multifunctional role of the Pitx2 homeodomain protein C-terminal tail. Mol. Cell Biol., 19(10):7001-10, 1999.

Arnold, W. H. \& Gaengler, P. Quantitative analysis of the calcium and phosphorus content of developing and permanent human teeth. Ann. Anat., 189(2):183-90, 2007.

Arrow, P. Prevalence of developmental enamel defects of the first permanent molars among school children in Western Australia. Aust. Dent. J., 53(3):250-9, 2008.

Ash, M. Development and eruption of the teeth. In: Wheeler's Dental anatomy, physiology and occlusion. Ash M. (Ed); $7^{\text {th }}$ edition. Philadephia, W.B. Saunders Company, 1993. pp.24-45.

Bauer, D. C.; Orwoll, E. S.; Fox, K. M.; Vogt, T. M.; Lane, N. E.; Hochberg, M. C.; Stone, K. \& Nevitt, M. C. Aspirin and NSAID use in older women: effect on bone mineral density and fracture risk. Study of Osteoporotic Fractures Research Group. J. Bone Miner. Res., 11(1):2935, 1996.

Berry, C. L. \& Nickols, C. D. The effects of aspirin on the development of the mouse third molar. A potential screening system for weak teratogens. Arch. Toxicol., 42(3):185-90, 1979.

Buhimschi, C. S. \& Weiner, C. P. Medications in pregnancy and lactation: part 1. Teratology. Obstet. Gynecol., 113(1):166-88, 2009.

Cambuddy mass percentage, 2009. Avalaible in: http://
www.Cambuddy.com/? left $=$ cocentration $\&$ right $=$ mass percentage.

Cappon, G. D.; Gupta, U.; Cook, J. C.; Tassinari, M. S. \& Hurtt, M. E. Comparison of the developmental toxicity of aspirin in rabbits when administered throughout organogenesis or during sensitive windows of development. Birth Defects Res. Dev. Reprod. Toxicol., 68(1):38-46, 2003.

Carbone, L. D.; Tylavsky, F. A.; Cauley, J. A.; Harris, T. B.; Lang, T. F.; Bauer, D. C.; Barrow, K. D. \& Kritchevsky, S. B.Association between bone mineral density and the use of nonsteroidal anti-inflammatory drugs and aspirin: impact of cyclooxygenase selectivity. J. Bone Miner. Res., 18(10):1795-802, 2003.

Chardi, H.; Acevedo, A. C. \& Risnes, S. SEM study of the development of rat incisor enamel hypoplasia under hypocalcemia induced by thyro-parathyroidectomy. Connect. Tissue Res., 39(1-3):157-64, 1998.

DeLaurier, A.; Boyde, A.; Horton, M. A. \& Price, J. S. Analysis of the surface characteristics and mineralization status of feline teeth using scanning electron microscopy. J. Anat., 209(5):655-69, 2006.

Egerton, R. F. Analytical Electron Microscopy. In: Physical Principles of Electron Microscopy: An Introduction to TEM, SEM, and AEM. Egerton, R. F. (Ed.). New York, Springer-Verlag, 2005. pp 164-5.

Femiano, F.; Lanza, A.; Buonaiuto, C.; Gombos, F.; Rullo, R.; Festa, V. \& Cirillo, N. Oral manifestations of adverse drug reactions: Guidelines. J. Eur. Acad. Dermatol. Venereol., 22(6):681-91, 2008.

Grace, E. G.; Sarlani, E. \& Kaplan, S. Tooth erosion caused by chewing aspirin. J. Am. Dent. Assoc., 135(7):911-4, 2004.

Hiller, C. R.; Robinson, C. \& Weatherell, J. A. Variations in the composition of developing rat incisor enamel. Calcif. Tissue Res., 18(1):1-12, 1975.

Koren, G. Special aspects of Perinatal \& Pediatric Pharmacology. In: Basic and clinical pharmacology. Katzung, B. G. (Ed.). 10 ${ }^{\text {th }}$ Ed. New York, McGraw Hill, 2007. pp.971-82.

Koshihara, Y.; Takamori, R.; Nomura, K.; Sugiura, S. \& Kurozumi, S. Enhancement of in vitro mineralization in human osteoblasts by a novel prostaglandin A1 derivative TEI-3313. J. Pharmacol. Exp. Ther., 258(3):1120-6, 1991. 
Lane, N. E.; Bauer, D. C.; Nevitt, M. C.; Pressman, A. R. \& Cummings, S. R. Aspirin and nonsteroidal antiinflammatory drug use in elderly women: effects on a marker of bone resorption. The Study of Osteoporotic Fractures Research Group. J. Rheumaol., 24(6):1132-6, 1997.

Lunardelli, S. E. \& Peres, M. A. Prevalence and distribution of developmental enamel defects in the primary dentition of pre-school children. Braz. Oral Res., 19(2):144-9, 2005.

Paine, M. L. \& Snead, M. L. Tooth developmental biology: disruptions to enamel-matrix assembly and its impact on biomineralization. Orthod. Craniofacial. Res., 8(4):239$51,2005$.

Prentice, A. Micronutrients and the bone mineral content of the mother, fetus and newborn. J. Nutr., 133(5 Suppl 2):1693S-9S, 2003.

Ranggard, L. \& Noren, J. G. Effect of hypocalcemic state on enamel formation in rat maxillary incisors. Scand. J. Dent. Res., 102(5):249-53, 1994.

Rouge, M. Dental Anatomy of rabbits. 2002. Avalaible in: http://www.vivo.colostate.edu/hbooks/pathphys/ digestion/pregastric/rabbitpage.html.

Rythén, M.; Norén, J. G.; Sabel, N.; Steiniger, F.; Niklasson, A.; Hellström, A. \& Robertson, A. Morphological aspects of dental hard tissues in primary teeth from preterm infants. Int. J. Paediatr. Dent., 18(6):397-406, 2008.

Salama, F. S. Microhardness and mineral contents of sound and carious human primary teeth. J. Pak. Dent. Assoc., 13(2):72-5, 2004.

Seymour, R. A. \& Rudralingham, M. Oral and dental adverse drug reactions. Periodontol., 46:9-26, 2008.

Smith, C. E. \& Nanci, A. Overview of morphological changes in enamel organ cells associated with major events in amelogenesis. Int. J. Dev. Biol., 39(1):153-61, 1995.

Susheela, A. K.; Bhatnagar, M.; Gnanasundram, N. \& Saraswathy, T. R. Structural aberrations in fluorosed human teeth: Biochemical and scanning electron microscopic studies. Curr. Sci., 77:1677-81, 1999.

Tredwin, C. J.; Scully, C. \& Bagan-Sebastian, J. V. Druginduced disorders of teeth. J. Dent. Res., 84(7):596-602, 2005 .
UCLEMA. Fundamentals for Electron Microprobe Analysis (EMPA), 2009. Avalaible in: http://www.geo.ucalgary.ca/ UCLEMA/EMPA1.html.

Woelfel, J. B. \& Scheid, R. C. Basic terminology for understanding tooth morphology. In: Dental Anatomy. Its relevance to dentistry. Woelfel, J. B. \& Scheid, R. C. (Eds). $5^{\text {th }}$ Ed. Baltimore, Lippincott Williams \& Wilkins, 1997. pp.87-118.

Xie, W. L.; Chipman, J. G.; Robertson, D. L.; Erikson, R. L. \& Simmons, D. L. Expression of a mitogen-responsive gene encoding prostaglandin synthase is regulated by mRNA splicing. Proc. Natl. Acad. Sci. U S A, 88(7):26926, 1991.

Zhang, J.; Eick, J. D.; Guo, D.; Dusevich, V.; Bonewald, L. F. \& Harris, S. E. Bmp4 is essential for tooth terminal cytodifferentiation: Gain-loss function study. IADR/ AADR/CADR 83rd General Session, 2005.

Zheng, S.; Deng, H. \& Bao, Y. The study on the clinical manifestation of developmental enamel defects in primary dentition. Hua Xi Kou Qiang Yi Xue Za Zhi, 21(3):2001, 4, 2003.

Correspondence to:

Dr. Shakila Nazir

Professor Department of Oral Biology

Baqai Dental College, Karachi

51-Deh Tor near toll plaza, superhighway Karachi

PAKISTAN

Email: shakila.nazir@gmail.com

Received: $20-08-2010$

Accepted: 06-10-2010 